\title{
Short Stature due to Ectopic Neurohypophysis: Case Report
}

\section{Mussa H. Almalki*, Badurudeen Mahmood Buhary, Imad Brema, Abdulrahman Almaghamsi, Saad Al Zahrani}

Obesity, Endocrine and Metabolism Centre, King Fahad Medical City (KFMC), Riyadh, Saudi Arabia

Email: *m2malki@yahoo.com

How to cite this paper: Almalki, M.H., Buhary, B.M., Brema, I., Almaghamsi, A. and Al Zahrani, S. (2017) Short Stature due to Ectopic Neurohypophysis: Case Report. Open Journal of Endocrine and Metabolic Diseases, 7, 89-95.

https://doi.org/10.4236/ojemd.2017.72009

Received: February 1, 2017

Accepted: February 25, 2017

Published: February 28, 2017

Copyright $\odot 2017$ by authors and Scientific Research Publishing Inc. This work is licensed under the Creative Commons Attribution International License (CC BY 4.0). http://creativecommons.org/licenses/by/4.0/

\begin{abstract}
Ectopic posterior pituitary is a disruption in the normal embryogenesis and is one of the rare but common causes of pituitary dwarfism. We report the MRI and clinical findings of a 13.5-year-old Saudi boy who was referred to the endocrine outpatient clinic with no significant complaints except for fatigue, exercise intolerance and short stature. Physical examination revealed short stature (below $2^{\text {nd }}$ centile) with normal body proportion without any dysmorphic features and prepubertal secondary sexual characteristics and genitalia. Hormonal profile revealed: low thyroxine level, low gonadotrophins, low testosterone, low cortisol and blunted growth hormone (GH) response to insulin induced hypoglycaemia. Bone age was of 5 years old. The MRI result concluded with a diagnosis of ectopic posterior pituitary. A diagnosis of posterior pituitary ectopia (PPE) with panhypopituitarism was made.
\end{abstract}

\section{Keywords}

Panhypopituitarism, Posterior Pituitary Ectopia, Growth Hormone Deficiency, Short Stature

\section{Introduction}

Ectopic posterior pituitary is a rare condition where "bright spot" is not seen at the sella. It can be associated with pituitary stalk transection syndrome and should be suspected when there is lack of pituitary stalk visibility and hypoplasia of the anterior hypophysis in a patient clinically presented with features of isolated growth hormone deficiency (IGHD)/multiple pituitary hormone deficiency (MPHD), but where the posterior pituitary function is usually maintained [1]. Magnetic resonance imaging (MRI) is essential for diagnosis. We present a case of short stature due to combined growth hormone and other anterior pituitary hormone deficiencies with ectopic posterior pituitary. 


\section{Case Report}

A 13.5 years old male Saudi presented to the Endocrine clinic for evaluation of short stature. His medical history revealed that he had fatigue and exercise intolerance. He had a normal birth at 39 weeks and was born with average birth weight $(2.6 \mathrm{~kg})$ and height $(48 \mathrm{~cm})$. He reached normal milestones till the age of eight months. He was sitting by 7 months of age and crawling at 10 months. $\mathrm{He}$ walked at 15 months. Apart from growth retardation, there was no evidence of chronic illness. He had right side undescended testes with surgical correction done three years ago.

He comes from a good socioeconomic status and has 8 siblings who are healthy and have no similar problems. His school performance was average. Physical examination revealed height of $123 \mathrm{~cm}$ (below $2^{\text {nd }}$ centile) and a weight of $26 \mathrm{~kg}$ (Figure 1), with a body mass index of $17.2 \mathrm{~kg} / \mathrm{m}^{2}$. His head circumference was $54 \mathrm{~cm}$ and his arm span of $123 \mathrm{~cm}$. He has no goiter, no skin or mucous changes or any pigmentations, no dysmorphic features, no bony deformities and no pubertal changes.

His genitalia are pre pubertal with bilateral testicles felt with less than $3 \mathrm{ml}$. Systemic examinations are unremarkable.

Laboratory data showed normal complete blood count, urea and electrolytes, liver function test and bone profile. Initial hormone studies showed ACTH 2.8 Pmol/l (1.6 - 13.9 Pmol/l), morning random cortisol 50 nmol/L (170 - 413 $\mathrm{nmol} / \mathrm{L})$, Short synathen $(250 \mathrm{mcg})$ test revealed that - baseline ACTH 5.8 Pmol/L (1.6 - 13.9 Pmol/l), and baseline cortisol level $112 \mathrm{nmol} / \mathrm{L}$ (170 - 413 $\mathrm{nmol} / \mathrm{L}), 30$ minute level $282 \mathrm{nmol} / \mathrm{L}(170-413 \mathrm{nmol} / \mathrm{L})$, and 60 minute level $364 \mathrm{nmol} / \mathrm{L}(170$ - $413 \mathrm{nmol} / \mathrm{L})$. TSH was $4.4 \mathrm{mIU} / \mathrm{L}(0.270-4.200 \mathrm{mIU} / \mathrm{L})$, with free T4 5.7 Pmol/l (12.0 - 22.0 Pmol/L), and free T3 $3.8 \mathrm{Pmol} / \mathrm{l}$ (3.1 - 6.8 $\mathrm{Pmol} / \mathrm{L})$. All normal values of the above parameters are shown in brackets.

LH $0.1 \mathrm{IU} / \mathrm{L}(1.7$ - 8.6 IU/L), FSH 0.1 IU/L (1.5 - $12.4 \mathrm{IU} / \mathrm{L})$, Prolactin 1254 $\mathrm{mIU} / \mathrm{L}(86-324 \mathrm{mIU} / \mathrm{L})$. Growth hormone $0.48 \mathrm{mIU} / \mathrm{L}(0.00-9.00 \mathrm{mIU} / \mathrm{L})$, IGF1 $3.25 \mathrm{nmol} / \mathrm{l}(28.6$ - $126.4 \mathrm{nmol} / \mathrm{L})$, IGFBP-3 $0.9 \mathrm{mg} / \mathrm{L}(2.2-7.8 \mathrm{mg} / \mathrm{L})$ were compatible with GHD. Celiac profile was negative.

Clonidine stimulation test showed: baseline growth hormone at $0.2 \mathrm{mIU} / \mathrm{L}$ (0.00 - $9.00 \mathrm{mIU} / \mathrm{L}), 30$ minute level $0.29 \mathrm{mIU} / \mathrm{L}(0.00-9.00 \mathrm{mIU} / \mathrm{L}), 60$ minute level $0.26 \mathrm{mIU} / \mathrm{L}(0.00-9.00 \mathrm{mIU} / \mathrm{L})$ and 90 minute level at $0.56 \mathrm{mIU} / \mathrm{L}(0.00$ $9.00 \mathrm{mIU} / \mathrm{L}$ ) resulting in no increase in growth hormone levels.

Insulin tolerance test was abnormal, resulting in confirmation of the diagnosis (Table 1).

$\mathrm{X}$-ray left hand showed a bone age of 5 years with delayed bone age more than two standard deviations of the chronological age (Figure 2).

The MRI pituitary gland revealed spontaneous high T1 nodule at the median eminence of the third ventricle with absent normal spontaneous T1 hyperintensity of the neurohypophysis indicating ectopic posterior pituitary. The anterior pituitary appears unremarkable. No convincing associated abnormality noted.

The supratentorial and the infratentorial structures appeared essentially 


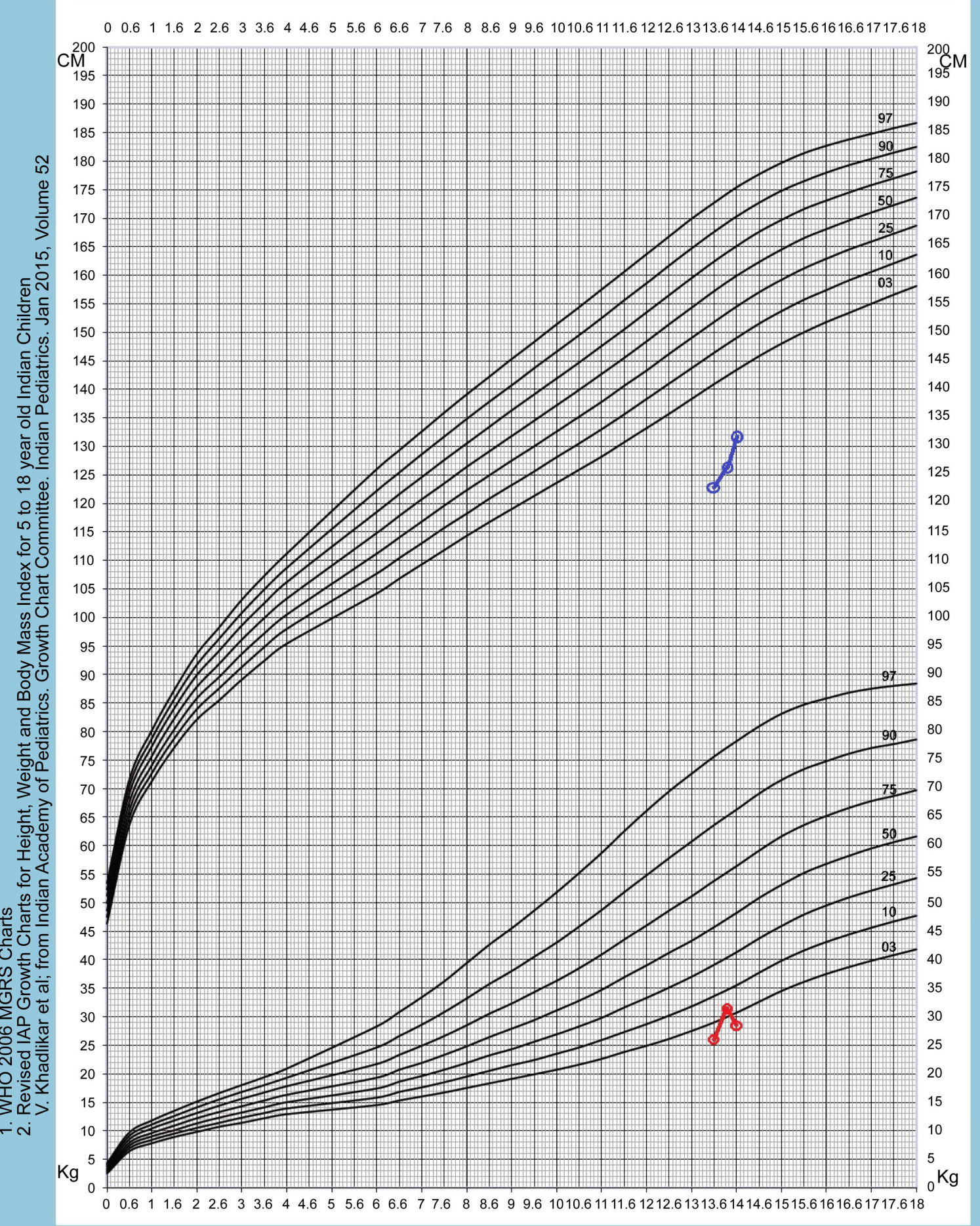

\section{AGE (Years)}

Figure 1. Growth Chart showing data at time of first visit, after 3 months follow up and after 6 months follow up. Height is shown in blue and weight is shown in red. 
Table 1. Insulin tolerance test.

\begin{tabular}{cccc}
\hline $\begin{array}{c}\text { Test } \\
\text { (normal range) }\end{array}$ & $\begin{array}{c}\text { Baseline } \\
\text { values }\end{array}$ & $\begin{array}{c}\text { After IV insulin injection } \\
\text { (after 30 minutes) }\end{array}$ & $\begin{array}{c}\text { After IV insulin injection } \\
\text { (after 45 minutes) }\end{array}$ \\
\hline $\begin{array}{c}\text { Blood glucose } \\
(4.4-7.8 \mathrm{mmol} / \mathrm{l})\end{array}$ & 4.3 & 2.8 & 2.1 \\
$\begin{array}{c}\mathrm{ACTH} \\
(1.6-\mathbf{1 3 . 9} \mathrm{Pmol} / \mathrm{l})\end{array}$ & 5.9 & 2.4 & 2.2 \\
$\quad \begin{array}{c}\text { Cortisol } \\
(200-700 \mathrm{nmol} / \mathrm{L})\end{array}$ & 87 & 34 & 32 \\
$\begin{array}{c}\text { Growth hormone } \\
(0.00-9.00 \mathrm{mIU} / \mathrm{L})\end{array}$ & 0.33 & 0.25 & 0.41 \\
\hline
\end{tabular}

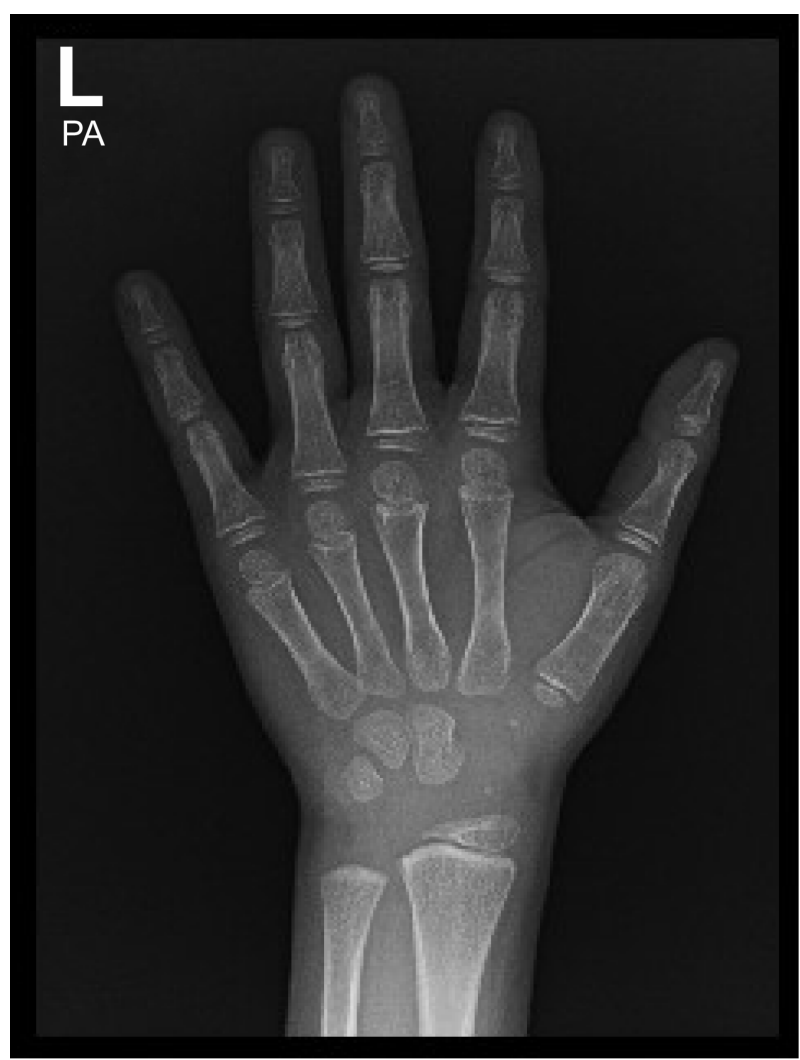

Figure 2. X-ray left hand.

unremarkable. The MRI result concluded with a diagnosis of ectopic posterior pituitary (Figure 3). The ectopic pituitary gland is pointed out in Figure 3(C).

From the results of the dynamic tests and pituitary MRI, the patient was diagnosed with Panhypopituitarism with growth hormone deficiency, adrenal insufficiency, secondary hypothyroidism and secondary hypogonadism due to ectopic posterior pituitary. Replacement therapy was started and currently he is on hydrocortisone $2.5 \mathrm{mg}$ tablets twice daily, Levothyroxine $75 \mathrm{mcg}$ tablet daily, recombinant human growth hormone $1 \mathrm{mg}$ injection subcutaneously daily. After 3 months of follow up he has gained height $(126.5 \mathrm{~cm})$ and weight $(31.8 \mathrm{~kg})$. After 6 months of follow up he has gained height $(132 \mathrm{~cm})$ and lost some weight $(28.4 \mathrm{~kg}$ ) (Figure 1). 

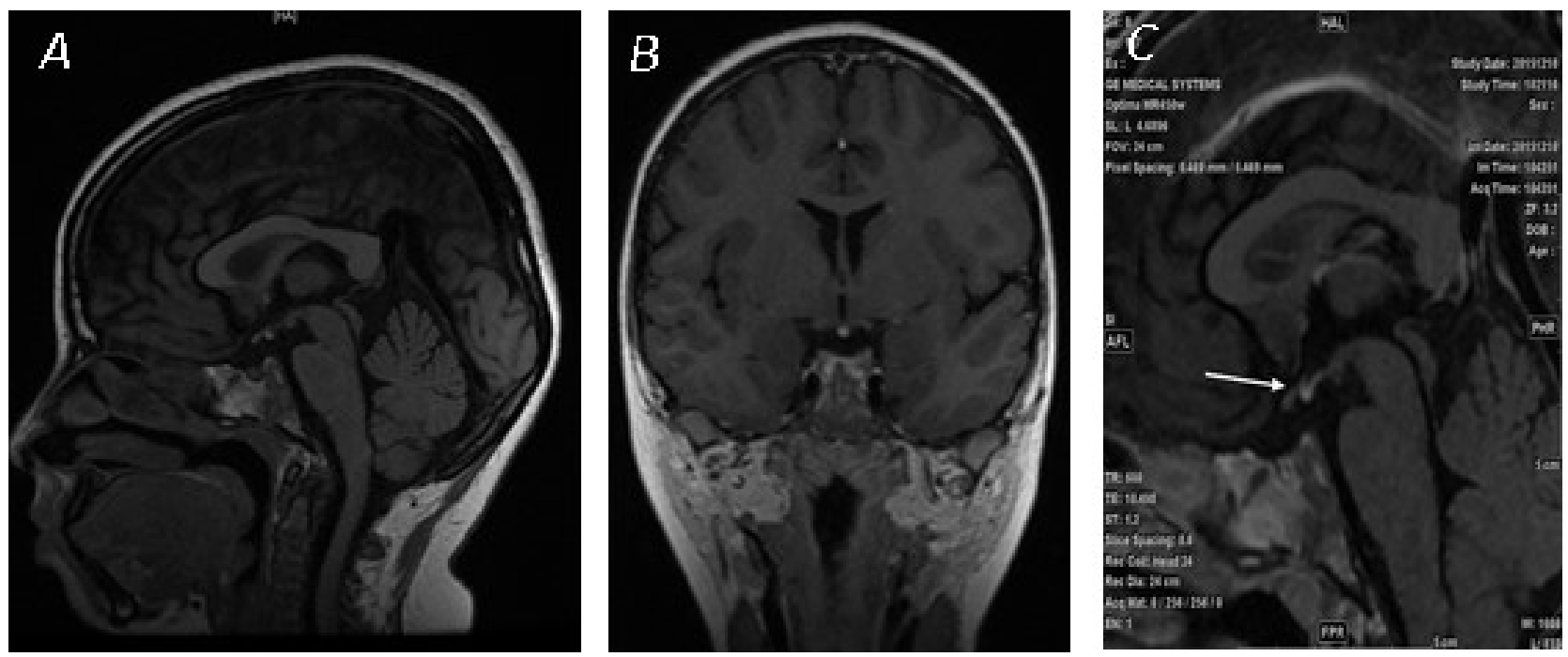

Figure 3. MRI T1-weighted images: (A) Sagittal, (B) Coronal and (C) Sagittal; showed spontaneous high T1 nodule at the median eminence of the third ventricle with absent normal spontaneous $\mathrm{T} 1$ hyperintensity of the neurohypophysis indicating ectopic posterior pituitary. The ectopic pituitary gland is pointed out in Figure 3(C).

Informed consent was obtained from the parents to publish this case.

\section{Discussion}

The ectodermal anterior pituitary evolves from the rathkes pouch while the neuroectodermal posterior pituitary forms from the diencephalon and should be connected with the infundibulum. An ectopic gland forms due to a faulty migration of the posterior lobe during embryogenesis, tumours, trauma, or surgical transection of the pituitary stalk [2] [3]. This rare condition occurs with hypoplasia or absence of the infundibular stalk, an empty pituitary fossa and exhibits features of growth hormone deficiency (short stature/pituitary dwarfism) and may also have features of various related abnormalities like congenital, central nervous system malformations, cardiac abnormality, facial abnormality etc. [4] [5]. Another common malformation is neonatal hypoglycemia [5]. The most common location of the ectopic lobe is along the median eminence in the floor of the third ventricle as in our case; however it can vary [6]. However our patient did not have any dysmorphic features and he had a proportionate body similar in size of a 6 to 7 years old boy.

Multiple hormone deficiencies are commonly associated with the ectopic posterior lobe, the most commonly occurring abnormality is of the anterior gland hormones related to dysfunction of the infundibulum. The neurosecretory cells of the posterior pituitary transport $\mathrm{ADH}$ and oxytocin along the infundibular stalk while the anterior pituitary transport hypothalamic releasing hormones via vessels along the infundibulum. This patient was diagnosed with Ectopic posterior pituitary with Panhypopituitarism consisting of Growth hormone deficiency, Adrenal insufficiency, Secondary hypothyroidism and Secondary hypogonadism.

Holoprosencephaly is one of the commonly associated midline anomalies 
which usually becomes apparent due to growth failure. Abnormal MRI mostly result with patients that have peak growth hormone levels less than $3 \mathrm{~g} / \mathrm{L}$. Research indicates patients with a visible infundibulum after contrast have less severe hormonal problems and are disposed to have isolated growth hormone deficiency [1]. Our patient's MRI study revealed evidence of a spontaneous high T1 nodule at the median eminence of the third ventricle with absent normal spontaneous T1 hyper intensity of the neurohypophysis indicating ectopic posterior pituitary. The anterior pituitary appears unremarkable. No convincing associated abnormality was noted. The supratentorial neither the infratentorial structures appeared essentially unremarkable. No signs of disturbed CSF flow. The mid sagittal images demonstrated a well formed and intact corpus callosum.

In one study evaluating the MRI of 103 patients, 72 patients were with Isolated GHD (IGHD) and 31 with Combined Pituitary Hormone Deficiency (CPHD)] [7]. MRI abnormalities were found in $48.6 \%$ patients with IGHD and $93.5 \%$ with CPHD. Jaundice, hypoxia, hypoglycemia and breech deliveries were commonly observed in ectopic posterior pituitary (EPP)/thin or interrupted pituitary stalk (PSA) group. EPP/PSA was found in $87.1 \%$ patients with severe GHD (peak GH $<3 \mu \mathrm{g} / \mathrm{L}$ or $<9 \mathrm{mIU} / \mathrm{L}$ ) as compared to $12.9 \%$ with mild to moderate GHD (peak GH: $3-10 \mu \mathrm{g} / \mathrm{L}$ ). Amongst CPHD, EPP/PSA was present in $80 \%$ of subjects with associated hypocortisolism \pm hypothyroidism as compared to $18.2 \%$ of subjects with hypogonadism.

No treatment is required for the ectopic pituitary as such, but rather for the recurrently associated growth hormone deficiency, or less frequently panhypopituitarism [8]. Growth hormone replacement and other deficient target hormone replacement are available in selected patients and can improve adult height. We replaced the deficient hormones and have observed an improvement in his growth and wellbeing over a period of 6 months.

\section{Conclusion}

In patients with idiopathic anterior hypopituitarism, they consider to rule out ectopic posterior pituitary and absent pituitary stalk on imaging. We emphasize the association of the absent pituitary stalk in ectopic pituitary gland and low growth hormone levels.

\section{Conflicts of Interest}

There are no conflicts of interest to declare in relation to this article.

\section{References}

[1] Chen, S., Léger, J., Garel, C., et al. (1999) Growth Hormone Deficiency with Ectopic Neurohypophysis: Anatomical Variations and Relationship between the Visibility of the Pituitary Stalk Asserted by Magnetic Resonance Imaging and Anterior Pituitary Function. The Journal of Clinical Endocrinology \& Metabolism, 84, 2408-2413. https://doi.org/10.1210/jcem.84.7.5849

[2] Saleem, S.N., Said, A.H. and Lee, D.H. (2007) Lesions of the Hypothalamus: MR 
Imaging Diagnostic Features. Radiographics, 27, 1087-1108.

https://doi.org/10.1148/rg.274065123

[3] Van der Linden, A.S. and Van Es, H.W. (2007) Case 112: Pituitary Stalk Transection Syndrome with Ectopic Posterior Pituitary Gland. Radiology, 243, 594-597. https://doi.org/10.1148/radiol.2432040385

[4] Mitchell, L.A., Thomas, P.Q., Zacharin, M.R., et al. (2002) Ectopic Posterior Pituitary Lobe and Periventricular Heterotopia: Cerebral Malformations with the Same Underlying Mechanism? American Journal of Neuroradiology, 23, 1475-1481.

[5] Maintz, D., Benz-Bohm, G., Gindele, A., et al. (2000) Posterior Pituitary Ectopia: Another Hint toward a Genetic Etiology. American Journal of Neuroradiology, 21, 1116-1118.

[6] Ginat, D.T. and Meyers, S.P. (2012) Intracranial Lesions with High Signal Intensity on T1-Weighted MR Images: Differential Diagnosis. Radiographics, 32, 499-516. https://doi.org/10.1148/rg.322105761

[7] Jagtap, V., Acharya, S., Sarathi, V., et al. (2011) Ectopic Posterior Pituitary and Stalk Abnormality Predicts Severity and Coexisting Hormone Deficiencies in Patients with Congenital Growth Hormone Deficiency. Pituitary, 15, 243-250. https://doi.org/10.1007/s11102-011-0321-4

[8] Sartor, K. (2002) Diagnostic and Interventional Neuroradiology: A Multimodality Approach. George Thieme Verlag.

Submit or recommend next manuscript to SCIRP and we will provide best service for you:

Accepting pre-submission inquiries through Email, Facebook, LinkedIn, Twitter, etc. A wide selection of journals (inclusive of 9 subjects, more than 200 journals) Providing 24-hour high-quality service User-friendly online submission system Fair and swift peer-review system Efficient typesetting and proofreading procedure Display of the result of downloads and visits, as well as the number of cited articles Maximum dissemination of your research work

Submit your manuscript at: http://papersubmission.scirp.org/

Or contact ojemd@scirp.org 